\title{
A FAZENDA DE SANTA CRUZ E A CRISE DO SISTEMA COLONIAL (1790-1815).
}

\author{
SÔNIA BAYÃO RODRIGUES VIANA
}

I) . - INTRODUÇÃO.

No presente trabalho procuraremos mostrar como funcionava a Fazenda de Santa Cruz, latifúndio explorado pela Coroa portuguesa e que anteriormente pertenceu aos jesuitas.

Nós nos detivemos no período de tempo compreendido entre 1790 e 1815 porque nessa época a Coroa tomou uma série de iniciativas visando tornar essa unidade produtora mais rentavel, tirando-a da decadência em que ela se achava desde que, com a expulsão dos jesuitas em 1759, passara a pertencer ao patrimônio real.

Por outro lado, cumpre-nos destacar que a atitude da Coroa portuguesa face a Santa Cruz neste momento está perfeitamente enquadrada dentro de uma política geral que buscava a revitalização de toda a colônia, em reação à crise que atravessava o sistema colonial com o surgimento do capitalismo industrial.

Assim, dentro do contexto histórico da época, tentaremos enquadrar Santa Cruz como um exemplo das iniciativas da Coroa portuguesa para superar as dificuldades que se thes antepunham; as medidas adotadas no incentivo ao desenviolvimento econômico da colônia, no período que nos propusemos focalizar, integram-se num sistema que visa superar a defasagem existente entre o processo de desenvolvimento do capitalismo industrial na Europa Ocidental, especificamente na Inglaterra, e o atraso da economia portuguesa, que não conseguira acompanhar tal processo.

Em fins do século XVIII, a mineração no Brasil entrou em franco processo de decomposição. 
Até o grande desenvolvimento da produção do café, que se firma em meados do século XIX, a agricultura brasileira não chegou a atingir grandes índices de produtividade, como se dera anteriormente no ciclo da cana-de-açucar. Ainda cultivava, porem, produtos típicos de uma economia monocultora, de grande extensão, como fora a nos ${ }^{\mathfrak{1}}$ sa desde os primeiros séculos da colonização: a cana-de-açucar e o algodão, principalmente. Este é, pois, um período em que os produtos agrícolas explorados são, de um modo geral, produtos de uma agricultura de subsistência; período de transição de nossa história, não só econômica mas tambem política, se lembrarmos que em 1808 se deu a transferência da família real portuguesa para o Brasil e, em 1814, a elevação deste à categoria de Reino Unido, fatos estes que tiveram enorme importância em nossa evolução posterior.

A essa altura, Portugal, como tambem a Espanha, encontra-se decadente desde a segunda metade do século XVIII, face as demais potências que se fortalecem no cenário europeu, sobretudo a Inglaterra.

O antigo sistema colonial, baseado no pacto colonial, que representava o exclusivismo do comércio das colônias para as respectivas metrópoles, estava em declínio devido a uma profunda e irreversivel transformação econômica: o surgimento do capitalismo industrial em substituição ao já decadente capitalismo comercial.

Este, até o século XVIII, dominara exclusivamente pois a indústria ainda estava na fase do artesanato, sem ter alcançado a fase capitalista .

Só a partir de meados deste século é que se delineia um capitalismo industrial, isto é, surge um capital industrial propriamente ditó, autônomo $\mathrm{e}$ independente do comercial, dedicado exclusivamente à produção manufatureira; desenvolveu-se em índices tão elevados que assumiu cada vez mais o domínio da economia européia. Isto levou ao declínio do antigo sistema colonial, característico do capitalismo comercial (1) .

O monopólio comercial inerente ao sistema colonial era desinteressante e prejudicial ao capitalismo industrial; a este interessava um comércio livre, que lhe permitisse melhor colocar seus produtos nos diferentes mercados mundiais. $O$ progresso do capitalismo industrial, na segunda metade do século XVIII, se voltou contra todos os monopólios, cujo desaparecimento foi cada vez mais considerado

(1). - Caio Prado Júnior. Editora Bràsiliense (São Paulo, 1966), pág. 125-6 - História Econômica do B̈rasil. 
como condição indispensavel ao seu desenvolvimento. Os monopólios ibéricos achavam-se, pois, num momento de crise; era-lhes impossivel adaptar-se à situação, nos mesmos moldes da Inglaterra e França, pois sua indústria não se desenvolvera, girando suas atividades exclusivamente em torno do comércio colonial, sendo-lhes impossivel abrir mão do monopólio, privilégio que constituia sua própria razão de ser.

Portugal tomou conhecimento dos perigos que se lhe antepunham, mas talvez não tenha tido plena consciência do que eles representavam ou das medidas realmente positivas a adotar ante a situação; a crise se apresentou, para os estadistas portugueses do final do século XVIII, primariamente como um conjunto de problemas que a monarquia absolutista tinha que resolver.

Em 1794, o bispo D. José Joaquim da Cunha de Azeredo Coutinho escreveu o Ensaio econômico sobre o comércio de Portugal $e$ suas colônias, obra que se tornou famosa, na qual focalizou os problemas coloniais (2).

Rodrigo de Sousa Coutinho, ministro da Marinha e Ultramar a partir de 1796, escreveu uma Memória sobre os melhoramentos dos domínios na América, que era um vasto e articulado plano de fomento da exploração econômica do Brasil (3). Buscava-se remover os obstáculos ao pleno funcionamento do sistema colonial na nova conjuntura; este trabalho de Rodrigo de Sousa Coutinho procurava definir um sistema de relações entre Portugal e seus domínios com grandes vantagens para o primeiro. Esses exemplos caracterizam uma preocudação geral nos paises ibéricos pela reorganização de sua exploração ultramarina.

Antes de abordarmos as medidas adotadas a partir de 1790 para um melhor desenvolvimento da Fazenda de Santa Cruz, faremos uma descrição da mesma a fim de melhor situarmos o leitor em nossa narrativa.

A Fazenda de Santa Cruz constituia uma porção da melhor terra existente no Brasil. Sua localização era uma das mais admiráveis distando dez a treze léguas de caminho do Rio de Janeiro. $O$ acesso à capital por terra era feito por caminhos não muito bons, mas podia

(2) . - J. J. da Cunha Azeredo Coutinho - Companhia Editora Nacional. (São Paulo, 1966), pág. 82 - Obras Econômicas (1794-1804) - Coleção "Roteiro do Brasil - Vol. I.

(3). - Citado por Fernando A. Novais - Tese de doutoramento para a Universidade de São Paulo, pág. 125 - Portugal e Brasil na crise do Antţo Sistema Colonial (1777-1808). 
ser alcançado tambem por mar, uma vez que a costa era paralela à estrada que, por terra, conduzia da fazenda até Sepetiba, praia onde terminava Santa Cruz do lado do mar.

O seu lado meridional banhado pelo mar de Sepetiba era cortado diametralmente pelos rios Itaguaí e Guandú, com fundo bastante para a penetração de embarcações a vela, de pequeno porte, o que, alem de outras condições locais, a valorizavavam bastante.

Seus terrenos podiam ser separados em duas grandes partes, desiguais e de natureza distinta, mas ambas de grande valor:

19). - A primitiva sesmaria de quatro léguas quadradas, adquirida pelos jesuitas a seus proprietários no século XVI, a parte mais antiga da fazenda e, ao mesmo tempo, a mais desenvolvida; estendia-se por um plano quase regular até a serra do Mar. Possuia fertilíssimos pastos, excelentes e singulares madeiras e abundância de lenha, de facil exportação. Aí situavam-se o Convento, a povoação e os belos campos com currais para o gado.

Nas encostas das matas localizavam-se, em 1799, dois engenhos de açucar, um em Itaguai, construido com toda grandeza, com dois ternos de moendas e movido a água; o outro, em Piauí, movido por bestas, numa excelente localização, à beira do mar, com facilidade de embarque dos produtos até mesmo a pé.

Ainda nesta primeira parte havia uma fábrica de farinha de mandioca e grandes plantações de cana, de mandioca, de legumes, arrozais, cafeeiros e algodoeiros, todos de excelente qualidade devido à fertilidade das terras.

$2^{\text {a) }}$. - Constituida pelas seis léguas quadradas restantes, adquiridas mais tarde, já no século XVII, tambem pelos jesuitas; era mais inculta que a anterior e assentava-se toda sobre as serras, dilatando-se a oeste para o sertão do Paraiba do Sul.

Possuia grande abundância de madeiras de excepcional qualidade e terras fertilíssimas, mas apresentava um grande problema: a dificuldade de transporte para os seus produtos, até o porto marítimo (4). No caso das madeiras, por exemplo, alem de ser dificil transportá-las por terra até o mar, uma vez aqui chegadas, restaria o problema da pouca profundidade dos rios por onde elas navegariam, sendo necessária a construção de embarcações apropriadas. A barra

(4) . - Revista de IHGB - Tomo 65 - 1902, págs. 301-2. "Memórias de Santa Cruz, seu estabelecimento e economia primitiva; seus sucessos mais notávèis, continuados do tempo da extinção dos denominados Jesuitas, seus fundadores, até o ano corrente de 1799" - 15-8-1799. 
do Itaguaí teria, mais ou menos, de sete a oito palmos de profundidade, só permitindo a entrada de embarcações não demasiado carregadas.

Em 1795, o Coronel Manoel Martins do Couto Reis, nomeado como administrador da fazenda de Santa Cruz, calculou em mais ou menos dois milhões de cruzados o valor das suas terras e diferentes produções, naquele momento (5).

\section{II). - HISTÓRICO.}

A). - Epoca jesuítica.

As origens da Fazenda de Santa Cruz datam do século XVI. porem ela só se desenvolveu realmente no século XVII, sob a administração dos padres da Companhia de Jesus do Brasil. Possuia aquela propriedade um total de dez léguas quadradas de extensão, imenso patrimônio que os jesuitas revestiram de todas as garantias e formalidades legais, abrangendo as terras situadas desde as ilhas de Guaraqueçaba e de Itingussú até a serra de Mata-cães em Vassouras. Pela Ordem Régia de 4-06-1727, procedeu-se pela primeira vez ao tombamento das suas terras, cujos autos foram dados por concluidos e autenticamente publicados a 17-5-1731. Coincidiu com as medições o caminho entre São Paulo e o Rio de Janeiro, que devia atravessa-la.

Concluido o Tombo, a Fazenda de Santa Cruz ficou com os seguintes limites: a freguesia de Sacra Família do Tinguá, em Vassouras; a linha do Curral Falso contígua à Freguesia de Guaratiba até o mar; os terrenos de Marapicú, a leste, e as terras de Mangaratiba, no ponto do Itingussú, a oeste. No decorrer do século XVII, ela foi a mais importante propriedade dos padres da Companhia de Jesus no sul do Brasil.

Em 1760, foi transformada em Fazenda Real e, depois, em Fazenda Imperial, quando da criação do Império no Brasil. Hoje, suas terras constituem a zona rural de Santa Cruz, no Estado da Guanabara.

Possuida pelos jesuitas, a fazenda conheceu na primeira metade do século XVII um intenso período de desenvolvimento da lavoura e da criação de gado.

(5). - Arquivo Nacional (A. N.) - Caixa (cx.) 507, pacote I, pacotilha 8, págs. 43-4 - Resposta de Manoel Martins do Couto Reis à carta que the fora enviada pelo Vice-Rei a 8-6-1795. 
Entretanto, devido às condições geográficas e climáticas da regitio em que estava localizada, os jesuitas tiveram que introduzir uma série de melhoramentos para que pudessem explora-la mais racionalmente.

Desta forma, realizaram uma série de obras hidráulicas, de grande envergadura, admiráveis para a época. Dadas as características do clima da região, bastante quente e chuvoso durante o verão, e do relevo da fazenda, com vastas campinas facilmente alagáveis nas épocas das grandes chuvas pelo transbordamento dos rios Itaguaí e Guandú, o que prejudicava de sobejo não só a lavoura mas tambem o gado, viram-se os jesuitas obrigados a realizar um conjunto gigantesco de obras, a fim de que pudessem tirar o máximo proveito das possibilidades oferecidas por esta sua propriedade, neutralizando os efeitos negativos dessas intempéries.

A Baixada Fluminense, onde estava localizada a Fazenda de Santa Cruz, inundava-se periodicamente durante o verão, inutilizando as plantações, matando o gado, destruindo os pastos; alem disso, havia terrenos dentro da fazenda que permaneciam alagados por todo $o$ ano, formando grandes brejos.

As obras que os jesuitas realizaram para vencer tais obstáculos foram fabulosas: canais de escoamento e irrigação, paredões, comportas, diques e pontes; elas já estão minuciosamente relatadas por outros autores.

O rio Guandú ou Ribeirão das Lages, que atravessava suas terras ao meio, aproximadamente, descia pelas seis léguas de terras de suas cabeceiras, bifurcava-se em dois ramos desiguais antes de atingir os terrenos mais baixos da fazenda. O maior de seus braços recebia aí o nome de Itaguaí ou Rio Grande; o braço menor, estreito e bastante sinuoso, lançava-se no oceano a uma relativa distância da embocadura do Itaguaí e era conhecido como rio Guandú.

A fazenda tambem possuia igreja, vasta residência de sobrado, hospedaria, escola de rudimentos e catequese para meninos, hospital, cadeia e diversas oficinas de trabalho: ferraria, tecelagem, carpintaria, olaria, fábrica de cal, fábrica de farinha, descasca de arroz, curtume, engenhoca de aguardente, engenho de açucar (em construção), estaleiro onde se fabricavam canoas; há referências à existência de uma oficina de prata lavrada. Havia, ainda, um açougue, uma pescaria na Ilha da Pescaria, onde havia grande quantidade de ostras e mariscos utilizáveis no fabrico da cal, alem de mais duas pescarias, uma na barra do rio Guandú e outra na foz do Itagu?í. 
$\mathrm{Na}$ agricultura, praticava-se a clássica policultura das grandes fazendas jesuíticas: mandioca, arroz, feijão, algodão, etc...

Sua principal fonte de lucros, porem, parecia advir do aluguel dos pastos da fazenda ao gado vindo das capitanias de Minas Gerais e de São Paulo, que aí permanecia engordando e descansando antes de ir para o mercado do Rio de Janeiro.

A criação de gado foi a grande atividade econômica desenvolvida pelos jesuitas em Santa Cruz. Seu gado era distribuido por 22 currais, convenientemente localizados pelos campos. Em cada curral havia um pastor ou campeiro e um ajudante, que residiam junto aos currais, para o que se construiu uma pequena senzala ao lado de cada curral. Os jesuitas chegaram a possuir mais de 11.000 cabeças de gado vacum nos campos de Santa Cruz, alem da grande quantidade de gado cavalar, de raça selecionada, dos ovinos, caprinos, suinos, do gado lanígero, sem se contar as aves e outros animais domésticos de uso cotidiano, existentes em abundância e variedade.

Para fazer frente a tantas e diversas atividades, utilizava-se principalmente a mão-de-obra escrava, como era comum na época, por ser ela a base da vida econômica de então em nosso país. Esses escravos, conforme suas aptidões, recebiam treinamento especializado nas oficinas da própria fazenda (pedreiros, torneiros, cavouqueiros). Os jesuitas teriam tido, de uma só vez, 1.500 escravos em Santa Cruz: os homens ocupavam-se principalmente da criação de gado, além de várias outras tarefas: construções, derrubada das matas, abertura de caminhos, limpeza e conservação dos campos, trabalhos nas oficinas, etc... As mulheres ocupavam-se principalmente da agricultura e da fiação e tecelagem do algodão.

$$
\text { B). - Epoca real. }
$$

Imediatamente após a expulsão dos jesuitas do Brasil (Lei de 3-9-1759), a Fazenda de Santa Cruz foi incorporada ao patrimônio real passando a ser dirigida pela burocracia administrativa portuguesa.

A partir de então, a decadência aí teria se "instalado", sobretudo no período compreendido entre 1765 a 1779 ou 1781 (6).

Toda sua produção, principalmente o gado, ficou em péssimo estado; a desorganização afetou a própria escravatura, que chegou a se rebelar. Em 1769, o Vice-Rei Conde de Azambuja baixou uma portaria a fim de que se apressassem as milícias necessárias para pren-

(6). - Op. cit., pág. 306 - "Memórias de Santa Sruz". 
derem os escravos sublevados em Santa Cruz, dando ordens inclusive para mata-los, se houvesse resistência (7) .

Nesta época, os documentos passam a destacar, com sintomática frequência, o lamentavel estado em que aquela propriedade se achava:

"achando-se a Fazenda de Santa Cruz, absolutamente perdi$\mathrm{da}$, sem rendimentos e no lamentavel estado que constará de um processo que pende no Juizo da Coroa contra o administrador..........." (8).

\section{III. - ESFORÇOS PARA O SEU DESENVOLVIMENTO.}

A partir de 1790, entretanto, a Fazenda de Santa Cruz será alvo do interesse da Coroa, que procurará recupera-la dentro dos limites possíveis, tentando torna-la mais rentavel. As razões que justificam semelhante atitude foram explicadas no início de nosso trabalho. Em 1791, surgem novas e mais bem concertadas disposições; decidiu-se que revivesse as antigas medidas jesuiticas; que os currais, as regas pastorais, o campo, as valas e os diques fossem cuidados, voltando ao estado original. Tambem foi determinado que os artigos mais preciosos e importantes da agricultura e de especial aceitação no comércio fossem adotados e cultivados e a escravatura repartida proporcionalmente pelas diversas atividades para que tivesse uma aplicação mais séria e corrente (9).

Em carta dirigida ao Secretário de Estado, o Inspetor Coronel Manoel Martins do Couto Reis, nomeado para inspecionar a propriedade, descreveu as medidas que pretendia adotar para modificar a situação de decadência ali existente. Em $1^{\circ}$ lugar, ele daria atenção à agricultura, procurando desenvolver os produtos mais rendosos e de maior aceitação no comércio. Depois, cuidaria da restauração do campo e da criação de gado, construindo currais e domesticando o gado bravio. Outro empreendimento que pretendia realizar, e realmente o conseguiu, foi a construção de dois engenhos de açucar de grandes proporções e muito bem construidos, que chegaram a ser alvo de muitos comentários na época. Alem destes engenhos, pretendia ainda construir uma série de outras "feitorias" menores para a cultura de vários "efeitos" de 1 a necessidade (10).

(7) - - A. N. Códice 618 - documento 13, pág. 27 - 17-5-1796 Cópia da Portaria do Vice-Rei Conde Azambuja apressando milícias para a prisão de escravos levantados.

(8) . - A. N. Cx. 507 - pacote I, pacotilha 3, documento 4 - Relatório do Inspetor - 18-6-1790.

(9). - Op. cit., pág. 310 - "Memórias de Santa Cruz".

(10). - A. N. cx. 507 - pacote 1 , pacotilha 12 , págs. 6-8. 
Em um ofício de Manoel Joaquim de Castro dirigido a Antônio de Araujo de Azevedo, dando sua opinião sobre o melhor plano de administração da Real Fazenda de Santa Cruz, para que esta desse mais lucros, lembrava o remetente a necessidade de se fomentar a agricultura, sendo que o melhor meio para isso seria procurar um homem capaz, que conhecesse os diversos terrenos, as diversas produções de que estes eram capazes, que soabesse distribuir a mão-de-obra pelas diferentes atividades a serem realizadas e que conhecesse as estações próprias para a smeadura de cada gênero, aproveitando-as bem (11) . Em 1811, em agricultor inglês, Samuel Bennet, chegou a Santa Cruz para dirigir trabalhos relacionados com o desenvolvimento agrícola da fazenda (12) .

As opiniões da época, aliás, eram muito favoráveis ao desenvolvimento da agricultura, atividade que julgavam a mais capaz de favorecer o progresso dos povos; estão de acordo com o surto de desenvolvimento das atividades rurais que se seguiu aqui, no Brasil, à decadência da mineração.

Vejamos em que aspectos se procurou desenvolver Santa Cruz, a fim de melhorar suas condições.

A). - Criação de gado.

A principal fonte de rendas da Fazenda de Santa Cruz estava no arrendamento de seus pastos para a engorda do gado que se dirigia ao mercado do Rio de Janeiro. Em 1790, o encarregado de fazer um exame minucioso da Fazenda de Santa Cruz, José Feliciano da Rocha Gameiro, afirmou que, com a exceção de algumas plantações de mandioca, os administradores tinham se contentado, até então, em alugar os pastos imensos da fazenda. Estes eram alugados a todos os que traziam gado de fora pagando de cada vez pela sua nutrição, durante um ou mais anos, 500 réis por cabeça, procedimento que já era comum no tempo dos jesuitas. Segundo ele, a capacidade desses pastos seria de até 10.000 reses (13); acontecia, porem, que esse gado vindo de fora a permanecia por tempo indeterminado, sem renovação da cobrança da taxa de entrada, o que impedia a Fazenda de alcançar melhores lu-

(11). - A. N. cx. 507 - pacote 2, pacotilha 20, documento 2, pág. 6 .

O documento está sem data, mas há um outro do mesmo autor, catalogado no mesmo pacote e sobre assunto semelhante datado de 10-3-1814 (N. da A.).

(12) . - A. N. cx. 507, pacote, pacotilha 23, pág. 6 .

Carta do Conde de Linhares ao Conde de Aguiar a fim de que este expedisse as ordens necessárias ao Superintendente da Fazenda de Santa Cruz, Leonardo Pinheiro de Vasconcellos, para que auxiliasse ao máximo os trabalhos que sob a direção do agricultor Samuel Bennet ali se iriam proceder 26-7-1811.

(13). - A. N. cx. 507, pacote 1, pacotilha 3, documento 5 . 
cros. Se o tempo de pastagem fosse fixad $s$, acrescentava ele, dentro de um determinado limite de teínpo, essa concessão daria um lucro consideravel, tendo-se em vista a extensão dos campos, sua situação e fertilidade.

Em 1794, a Junta da Fazenda tentou corrigir tal situação, ordenando, pela Provisão de 10-7-1794, que os 500 réis fossem cobrados anualmente; entretanto, a medida levantou uma série de protestos, o que fez com que a Junta suspendesse a resolução (14). Alem do gado vindo de fora e que aí permanecia até ser negociado no Rio de Janeiro, Santa Cruz desenvolveu uma criação particular, para atender às suas próprias necessidades (alimentação do pessoal administrativo, dos escravos, etc...) e com fins comerciais tambem.

Os talhos da cidade eram explorados pela Câmara Municipal, que percebia o emolumento de sua arrematação, a qual era feita anualmente, com demasiados subornos. O Conde de Rezende julgava que a exportação do gado de Santa Cruz seria mais lucrativa se a Coroa tornasse privativos daquela fazenda todos os talhos da cidade, calculando o rendimento assim obtido em 50 a 60 mil cruzados anuais, tendo-se em vista que a cidade então consumia por ano 15.000 cabeças de gado (15)

A fim de melhorar a produção, domesticou-se o gado que se tornara bravio; apesar de trabalhosa, tal providência foi valiosa pois permitiu uma melhoria geral do rebanho, que antes pouco produzia, quer fosse por morte, ou pela falta de trato ou por roubo; outra medida adotada visando esse mesmo objetivo foi a compra de vitelas selecionadas no Caminho de Minas Gerais, a fim de aumentar o número de crias reprodutoras. A manteiga e o queijo eram subprodutos do gado vacum fabricados em Santa Cruz.

Além do gado vacum, a fazenda criava tambem o lanígero, o equino, o suino; esta produção se desenvolveu aos poucos, ocorrendo, porem, que a porcentagem do gado vacum era sempre bastante superior à dos demais, pois era mais lucrativo, na época explora-lo. Em 1793, o Inspetor Coronel Manoel Martins do Couto Reis referia-se à necessidade da existência de um rebanho de pelo menos 5.000 ovelhas, que deveriam ser conservadas, produzindo anualmente mais de 2.000 arrobas de lã para o comércio; este total poderia ser atingido se a fa-.

(14) . - Revista do IHGB - Tomo V, 1843 - págs. 175-8. "Lucro Geral da Fazenda de Santa Cruz".

(15). - A. N. cx. 507, pacote 1, pacotilha 5, págs. 2-3.

Carta do Conde de Rezende dando notícias de Santa Cruz - 27-5-1752. 
zenda adquirisse 400 crias de boa raça e às deixasse procriar (16). Segundo o mesmo Inspetor, a criação de aves domésticas estava naquele momento pouco desenvolvida.

O desenvolvimento da criação de gado foi uma das proposições feitas como sendo a de maior importância para a recuperação de Santa Cruz, em 1790. Na opinião de muitos, seria bastante vantajoso que se tivesse novamente os 22 currais da época dos jesuitas, colocando-se em cada um 400 vitelas de raça selecionada, de modo que no todo houvesse pelo menos 8.000 cabeças, quantidade suficiente para produzir anualmente 4.000 crias. Estas crias vendidas pelo menor preço que pudessem alcançar no Rio de Janeiro, renderiam 25 contos e 600 mil réis a S. M. em dinheiro; haveria o gado necessário para a manutenção das esquadras que chegavam e se demoravam no Rio de Janeiro, independente das remessas das capitanias de serra acima que, ou não desciam a tempo, causando a falta de carne, ou chegavam com as boiadas magras, cansadas e doentes, como costumava ocorrer; alem disso, seriam evitadas as consideráveis despesas que fazia o Erário só neste gênero. A população do Rio de Janeiro compraria a carne gorda e saudavel, muito superior às estrangeiras (17). A carne de vaca foi um dos gêneros fundamentais do consumo colonial, juntamente com a mandioca, o arroz; o feijão.

Apesar das frequentes referências à importância da criação do gado, novos administradores sempre voltavam a notar a deficiência deste ramo de atividades. Em 1815, Francisco Cordeiro da Silva lembrava algumas medidas necessárias ao melhor progresso da criação de gado: zalas;

$\left.1^{\circ}\right)$. - reparação dos currais existentes e suas respectivas sen-

$\left.2^{\circ}\right)$. - obrigação dos campeiros em residir na senzala do curral que lhe pertencesse, a fim de conserva-la em bom estado, a pastorear seu rebanho, cuidar dos animais, tratando de suas doenças e ferimentos;

$\left.3^{\circ}\right)$. - a revista do gado de cada curral ferrando-o com uma marca, além do ferro geral, que indicasse o curral ao qual pertencia, a fim de evitar confusões nas revistas dos outros currais; esta marca seria o número do curral, adaptado ao ferro geral: quando se passasse

(16). - A. N. Códice 618 - documento 25, págs. 52-104.

Plano do Tenente Coronel Manoel Martins do Couto Reis, pelo qual mostrava os avultados interesses que se podiam tirar da Real Fazenda de Santa Cruz - 18-12-1793.

(17). - Op. cit., pág. 313 - "Memórias de Santa Cruz". 
au gado de outro curral, era só trocar o número no ferro geral; os currais, portanto, deveriam ser numerados:

$\left.4^{\circ}\right)$. - deveria haver uma pastagem e curral perfeitamente separados dos outros, para uso do gado doente;

59). - demarcação para cada curral de um distrito designado por limites naturais, como as valas e rios, que serviria unicamente para a pastagem de sua manada;

$\left.6^{9}\right)$. - estabelecimento de pastos de reserva tambem;

$7^{\circ}$ ). - dar-se-ia toda atenção à abertura de valas (já iniciada no momento), para levar água corrente aos currais; onde isso não fosse possivel, deveriam ser mantidos bem limpos os tanques que os jesuitas haviam construido para tal fim;

$8^{\circ}$ ). - para a pastagem do gado de fora, em viagem, seria destinada uma parte do campo, o mais separada possivel dos currais de criação, para evitar o contágio das epizootias, com que algumas vezes esse gado vinha contaminado (18). Portanto, em 1815, havia ainda dois tipos fundamentais de gado: o pertencente à fazenda propriamente e aquele que era engordado nos seus campos mas que pertencia a particulares.

A conservação dos campos de p̣astagem do gado vacum foi outro objeto da atenção dos administradores no período por nós estudado; a construção de valas' para escoamento dos brejos surgidos com as enchentes, a limpeza das já existente e a tentativa de desvio do rio Itaguai foram algumas das medidas tomadas neste sentido.

\section{B). - A Agricultura.}

Em vários documentos, são constantes as referências à fertilidade das terras de Santa Cruz para o cultivo de praticamente todos os gêneros agrícolas; alem de férteis, eram bastante extensas, sendo possível desenvolver-se grandes plantações de mandioca, milho, arroz, feijão, algodão, cana-de-açucar, café, etc .

De fato, Santa Cruz revelou-se como uma unidade produtora que buscava produzir todo o necessário à sua manutenção, sendo o excesso produzido remetido à Provedoria. Ela nunca foi um grande latifúndio monocultor visando exclusivamente a exportação, como a maioria dos latifúndios brasileiros da era colonial.

(18). - A. N. cx. 507, pacote 2, pacotilha 25 , documento 4 , págs. 6-8. 
Seu desenvolvimento agrícola foi muito prejudicado pela ocorrência de períodos de grandes secas, seguidos por chuvas abundantes, os documentos se referem às secas como às inundações provocadas pelas chuvas, ao apodrecimento das colheitas (feijão, algodão) e à presença de pragas de lagartas (19).

Quando em 1811, Samuel Bennet, agricultor inglês chegou à Fazenda de Santa Cruz para ali dirigir uma série de trabalhos (em fins de 1814 chegou a ser nomeado administrador), lembrou ele a necessidade de se utilizar o arado nos serviços da agricultura, prática até então inexistente em nosso meio, onde a técnica de preparação do solo para a semeadura ainda se encontrava em estágio bem rudimentar. Utilizava-se os mesmos processos do início da colonização; o aperfeiçoamento técnico da agricultura era praticamente nulo em fins do século XVIII, assim continuando durante o início do século XIX: continuava-se a usar o processo primtivo da "queimada", já praticado pelos indígenas anteriormente. Dos instrumentos agrícolas só se conhecia a enxada.

Segundo o mesmo Samuel, um arado com dois homens e quatrc bois substituiriam 300 escravos nos serviços das plantações por cada dia, trabalhando mais e melhor do que estes (20).

No Rio de Janeiro, pelo que nos parece ante os termos do documento, não havia oficinas capazes de fabricar arados, a não ser a de um ferreiro inglês, conhecido de Samuel Bennet que o indicou para tal serviço; chamava-se Smith e estava estabelecido no largo do Rosário, já tendo sido empregado de Lord Strangford.

Defendeu tambem Samuel Bennet o cercamento das terras com a plantação de boas sebes, para o que os espinheiros do Brasil eram, na sua opinião, muito superiores aos da Europa; sua foi tambem a idéia de formar em Santa Cruz uma horta experimental e um viveiro de plantas. Segundo Bennet, naquele momento (1811) havia na fazenda a quantidade suficiente de sementes para tal fim, inclusive um barril cheio de sementes de pinhão ou abeto, que alem de produzir o alcatrão, era valioso tambem na construção de mastros para navios, servindo ainda como planta ornamental. Caso suas experiências se

(19) . - A. N. cx. 507, pacote 1, pacotilha 9, págs. 5-9. Relação dos serviços designados e distribuidos na Real Fazenda de Santa Cruz, è feitorias anexas -1796 .

(20) . - A. N. cx. 507, pacote 2, pacotilha 20, págs. 37-9 - Carta de Samuel Bennet ao Conde de Linhares, dando notícias das providências a serem adotadas em Santa Cruz - S/D (o documento deve ser de 1811, segundo carta do Conde de Linhares ao Conde de Aguiar - nota 12) - (N. A.). 
revelassem positivas, podejam ser ampliadas em mais vasta escala (21).

\section{1. - A mão-de-obra.}

Como exemplo de um grande latifúndio colonial, Santa Cruz utilizava sobretudo a mão-de-obra escrava negra; mas há notícias tambem do emprego do elemento indígena e do branco livre.

Em 1797, o Coronel Manoel Martins do Couto Reis referia-se à prisão de 18 índios desertores e às providências para evitar que outros, no momento conduzindo boiadas no caminho de São Paulo, fizessem o mesmo (22).

Uma proporção surpreendente da mão-de-obra escrava era especializada. Há, nos documentos, referências constantes a escravos oficiais carpinteiros, pedreiros, ferreiros, etc... Nos engenhos, a mão-de-obra especializada era utilizada em várias funções. Os trabalhadores livres e assalariados eram utilizados nas funções de direção e nas funções especializadas: feitores, mestres, purgadores, caixeiros (23), etc. . Existia, porem, sempre em número bem menor que a mão-de-obra escrava; na Relação dos recibos e férias que mostram a quem se fez pagamentos por conta da Real Fazenda de Santa Cruz, de $1^{\circ}$ de janeiro até 31 de dezembro de 1794 há, por exemplo vários recibos do mestre do engenho de Itaguaí (24).

A grosso-modo, a escravatura de Santa Cruz era avaliada em 1.500 pessoas, quantidade considerada insuficiente para a realização das tarefas da fazenda uma vez que vários escravos eram deslocados para serviços fora dela; devemos lembrar que a fazenda pertencia ao Estado; muitas vezes, seus escravos eram requisitados para trabalhar nas obras públicas e outras atividades de interesse da administração real, fora do território de Santa Cruz (25).

Em 1804, ao se fazer um levantamento do número de escravos necessários ao custeio geral e conservação do campo, cultura de mandioca e fabrico e extração de farinha para as tropas de linha, segundo

(21). - A. N. cx. 507, pacote 2, pacotilha 20, págs. 37-9 - op. cit.

(22) . - A. N. cx. 507, pacote 1, pacotilha 10, pág. 1 - Carta de Manoel Martins do Couto Reis ao Vice-Rei sobre a prisão de índios desertores - 5-3-1797.

(23). - Caixeiros eram aqueles que faziam as caixas em que o açucar era acondicionado (N. da A.).

(24). - A. N. cx. 507, pacote 1, pacotilha 8, pág. 37-40.

(25). - A. N. cx. 507, pacote 1, pacotilha 3, documento 4, págs. 12-4; relatório do Inspetor da Fazenda de Santa Cruz - 18-6-1790. 
determinações reais, o Coronel Manoel Martins do Couto Reis avaliou os escravos de Santa Cruz num total de 1.529 pessoas, nem todas empregadas no serviço da fazenda uma vez que desse total se deveria abater: os velhos, os enfermos, os desertados, os destacados para destinos e lugares, os de ofícios mecânicos (como, por exemplo, os ocupados no trem de S. M., nas obras de fortificações, etc...) e os menores de ambos os sexos (26).

Por várias vezes, os documentos se referem à necessidade da volta para a fazenda dos escravos destacados para serviços fora dela, dada a insuficiência do número dos mesmos nela existente para realizar as tarefas que aí se faziam precisas, tais como a conservação das valas para escoamento e irrigação dos campos, o conserto dos diques arrombados pelas enxurradas, etc...

A mão-de-obra livre, assalariada e especializada, se fazia presente em maior quantidade principalmente quando da realização de obras na fazenda, como ocorreu quando da construção dos engenhos de Itaguai e do Piaui, e no funcionamento destes.

Como era típico do latifúndio colonial, Santa Cruz possuia um conjunto de oficinas, cujas atividades eram indispensáveis ao seu funcionamento: oficinas de carpinteiros, serralheiros, calafates, curtidores, oleiros, manteigueiros, tecelões, etc... Ai nesses estabelecimentos utilizava-se escravos como aprenđizes; o treinamento desses escravos nos estabelecimentos de ofícios e artes levava a um aumento do seu preço: em geral, valiam três vezes mais do que o escravo sem ofício. Francisco Cordeiro da Silva Torres lembrava a necessidade de se impulsionar esses estabelecimentos, colocando em sua direção mestres hábeis e destinando para aprendizes os moleques mais jeitosos "segundo sua propensão natural" (27). Samuel Bennet julgava que os escravos deveriam ser melhor instruidos e que se thes deveria despertar $\mathrm{c}$ gosto pela limpeza, regularidade e método em tudo o que fizessem (28); isto, sem dúvida, tornaria o seu trabalho bem mais produtivo.

\section{2. - Posse das terras.}

Além das terras cultivadas diretamente pela administração da fazenda e das concedidas aos escravos para fazerem suas roças, era co-

(26) . - Revista do IHGB - Tomo V - 1843 - págs. 183-6. "Carta de Manoel Martins do Couto Reis ao Desembargador Manoel C. S. Gusmão" - 16-11-1804.

(27) . - A. N. cx. 507, pacote 2, pacotilha 25, documento 14, págs. 52-65. Observações sobre a administração da Real Fazenda de Santa Cruz 15-12-1815.

(28). - A. N. cx. 507, pacote 2, pacotilha 20, págs. 37-9; op . cit. 
mum em Santa Cruz o aforamento de suas terras a foreiros nacionais ou imigrantes.

O costume de se aforar terras incultas já havia no período em que a fazenda pertenceu aos jesuitas; segundo Saldanha da Gama, naquela época os foreiros eram em número de vinte e sete, total esse que permaneceu mais ou menos estavel até o confisco dos bens da Companhia de Jesus, aumentando daí em diante. Quando, em meados do século passado, o autor redigiu a sua História da Imperial Fazenda de Santa Cruz, calculou o seu número em setecentos, distribuidos pelos terrenos da imensa propried_de.

Em documento da época, há uma relação dos foreiros que residiam e cultivavam sítios nas terras de Santa Cruz, com as importâncias por eles pagas pelo uso desses sítios no período de janeiro a dezembro de 1794 . Além do nome dos foreiros, o documento especifica os locais ocupados por cada um deles, onde tinham suas casas, se plantavam e residiam, se só plantavam, etc... (29).

Outros documentos nos informam sobre o mesmo assunto; por exemplo, a Relação dos foreiros da Fazenda de Santa Cruz, comprendidos entre a Fazenda da Pedra, Sepetiba e caminho do Piahy e a Relação dos foreiros que se acham fora da demarcação do Engenho do Piahy pelo lado da Fazenda que parte com o Carmo até o Rio Guandu, ambos de 19-9-1804, em que se especifica a data da entrada dos foreiros nas terras de Santa Cruz, seus nomes, locais onde se situavam dentro da fazenda e o valor de seus arrendamento (30).

As terras tambem eram aforadas a imigrantes, tendo-se conhecimento da vinda de espanhois e chineses em 1814.

Segundo a Ordem ao $1^{o}$ Administrador e Tesoureiro da Real Fazenda de Santa Cruz, de 19-6-1814, este funcionário deveria assistir aos imigrantes espanhois ai chegados durante um ano a partir do dia em que chegassem ao porto de Sepetiba. Cada um desses imigrantes, maior de sete anos, deveria receber, por mês, três mil e duzentos réis, sendo que os de menor idade deceberiam mil e seiscentos réis, devendo serem acomodados até quando fossem transportados para a Barra do Bom Jardim, onde S. A. R. lhes havia concedido terras em afo-

(29). - A. N. cx. 507, pacote 1, pacotilha 8, págs. 31-6. Relação da cobrança feita aos foreiros, compreendidos em Terras de Santa Cruz de janeiro a dezembro de 1794 . 14-5.

(30) . - A. N. cx. 507, pacote 2, pacotilha 17, documento 4 - pág. 
ramento para suas lavouras na forma do Decreto de 26-7-1813 (31). Para cada família deveriam ser levantadas casas no Bairro do Bom Jardim com proporções para a acomodação de cada uma conforme o número de pessos que a compusesse. Deveriam ser emprestados a cada família: uma vaca, um boi, uma égua, um potro, duas ovelhas, um carneiro, uma enchó, um martelo, dois formões, os ferros necessários para eles aprontarem seus arados e as sementes necessárias para suas plantações do primeiro ano. A cada homem "maior de sete anos" se emprestaria uma enxada, um machado, uma foice e um serrote. Esta Real Determinação deveria ser anotada no competente Livro da Administração e se daria como certidão a cada um dos chefes das famílias.

Leonardo Pereira de Vasconcelos comunicou ter admitido como foreiros alguns chinas, que aí se estabeleceram neste mesmo ano de 1814 (32). Para eles foram compradas 30 enxadas, 10 foices grandes e 11 foices pequenas; um deles recebeu 4.800 réis para as despesas na sua jornada com os demais, desde a cidade até Santa Cruz (33).

Em 1797, o Coronel Manoel Martins do Couto Reis, então administrador de Santa Cruz, dizia ter sido procurado por pessoas que desejavam arrendar ou aforar algumas porções de terras da fazenda, para nelas levantar engenhos de açucar e aguardente. Na sua opinião, tal concessão seria utilissima, tanto pelos dízimos e alfândegas como pelo foro anual que lhe corresponderia e tambem por ser uma forma admirável de se cultivar tantas terras incultas e distantes. Ele tinha dúvidas, porem, se os poderes que possuia para conceder foros incluia a concessão para a instalação de grandes fábricas, como por exemplo se fazia nas terras dos Viscondes de Asseca, principalmente nas dos Campos Goitacas, em que havia muitas e grandes fábricas de açucar (34).

(31). - A. N. cx. 507, pacote 2, pacotilha 24, documento 5-pág. 29. Ordem ao $1^{\text {9 }}$ Administrador e Tesoureiro da Real Fazenda de Santa Cruz, para aí receber os espanhóis a quem a S. A. R. aforara terras na Barra de Bom Jardim - 19-6-1814.

(32). - A. N. cx. 507, pacote 2, pacotilha 24, pág. 57. Carta de Leonardo Pereira de Vasconcellos ao Sr. Antonio de Araujo de Azevedo, sobre distribuição de terras de Santa Cruz - 3-9-1814.

(33). - A. N. cx. 507, pacote 2, pacotilha 24, pág. 56. Conta das ferramentas que se compraram para os chinas empregados na Real Fazenda de Santa Cruz - 26-8-1815.

(34) . - A. N. ex. 507, pacote 1, pacotilha 10, págs. 3-4. Representação de Manoel Martins do Couto Reis dirigida a S. M. Rainha de Portugal sobre assuntos referentes à Fazenda de Santa Cruz - 16-3-1797. 
Muitas vezes, a ocupação dessas áreas incultas se fazia de forma jlegal. Em outro documento, o Superintendente Leonardo P. de Vasconcelos ressaltou a necessidade de uma visita anual pelo centro da fazenda por dois motivos: o primeiro seria o de saber dos intrusos que progressivamente se introduziam nas terras das quais, às vêzes por ignorância, não solicitavam a S. A. R. a concessão, mesmo sem intenção de fraudar a Real Fazenda nos seus legítimos foros; o segundo seria efetuar a divisão dos sítios, terrenos e cultivados, cujas demarcações não podiam ser feitas de uma só vez. A segunda sesmaria de seis léguas quadradas estava quase toda ocupada por intrusos, segundo ele (35).

O problema do uso ilegal das terras de Santa Cruz já existia em 1786, quando se verificou que pessoas estranhas, sem autoridade e permissão legítima, aí possuiam plantações de arroz e outros produtos (36).

A atuação dos foreiros mesmo legalmente instalados, por sua vez, nem sempre estava de acôrdo com os interesses da fazenda: em 1781, se dava parte da grande destruição que eles tinham feito e continuavam fazendo nos matos virgens de Santa Cruz (37). Pelos mesmos motivos, vários deles foram expulsos das terras que ocupavam na fazenda, em 1787 (38).

Era comum, na época colonial, o aforamento de terras nos latifúndios, a fim de que os foreiros admitidos constituissem mão-de-obra em reserva, para eventuais necessidades (39); em Santa Cruz, os documentos não nos dão a entender essa função, embora a hipótese não nos pareça de todo improvavel; o que as fontes comumente revelam é o interesse da administração em perceber os foros referentes a tais concessões.

(35) . - A. N. cx. 507, pacote 2, pacotilha 24, págs. 64-5. Carta de Leonardo Pereira de Vasconcellos ao Sr. Antônio de Araujo de Azevedo sobre posse de terras na Fazenda de Santa Cruz - 15-10-1814.

(36) . - A. N. cx. 507, pacote 1, pacotilha 3, pág. 29. Cópia de uma informação sobre plantações que pessoas estranhas tem feito em terras dessa Fazenda de Santa Cruz - 5-5-1786.

(37) . - A. N. Códice 618, documento 27 - págs. 116-7. Cópia das cartas escritas pelo Administrador da Fazenda de Santa Cruz ao Inspetor dando parte da grande destruição que faziam os foreiros nos matos virgens - 4-5-1781.

(38). - A. N. Códice 618 , documento 28 , págs. 118-9. Certidão pela qual constam-os nomes dos foreiros expulsos, pela Real Fazenda de Santa Cruz por arruinarem ou destruirem os matos e outros danos - 26-2-1787.

(39). - Jacques Lambert. Editora da Universidade de São Paulo, 1969, pág. 95. América Latina - Companhia Editora Nacional. 


\section{3. - Produtos.}

Uma fonte de recursos de consideravel valor eram as madeiras, bastante abundantes na fazenda de Santa Cruz. Quando de sua chegada à mesma em 1811, Samuel Bennet afirmou que o estado em que se achavam as árvores exigia atenção imediata. Como inglês, ele as considerava árvores bravas e lamentou não serem elas cultivadas e bem reguladas: as de mais valor estavam sufocadas pelas menos valiosas e fracas por falta de lugar conveniente. Mesmo as mais inferiores poderiam dar alguma renda, se vendidas como lenha. Na sua opinião, Santa Cruz continha dentro de si os meios para o seu próprio melhoramento; a quantidade e a qualidade das madeiras era tal que, seguindo-se um judicioso sistema de lavrar e escolher a madeira, os lucros poderiam ser perenes, fornecendo renda imediata e infalivel à Coroa (40). Ele ainda recomendava a conservação das matas; o cume dos montes pequenos deveriam conservar-se arborizados; naquela época, ocorrera um corte desregrado de árvores em um dos montes de Santa Cruz que não permitiria, nunca mais, que elas tornassem a crescer naquele local.

Aliás, as matas litorâneas, entre as quais as de Santa Cruz, eram de melhor qualidade e mais facil acesso que as do interior do país; foram muito utilizadas no consumo local e, apesar das leis que procuravam restringir o seu desperdício, estas nunca foram cumpridas. O próprio atraso técnico da agricultura, que levava ao abandono dos terrenos quando estes se tornavam fracos, levava ao desmatamento indiscriminado, a fim de se utilizar as terras onde se localizavam as reservas florestais, geralmente muito férteis, na cultura dos produtos agrícolas .

O Brasil contribuiu com suas madeiras para a restauração naval da metrópole, mas a indústria não teve grande desenvolvimento, por falta de técnica e organização eficiente; só a partir de 1810 , o aproveitamento de nossas madeiras se tornou mais intenso, quando os ingleses receberam autorização para explorar nossas matas (41).

Entre os gêneros de primeira necessidade cultivados em Santa Cruz destacavam-se: a mandioca, o arroz, o feijão, e o milho, cultivando-se tambem a cana-de-açucar, o café, o algodão e o anil (indigoeiro) .

No começo desta ncva fase (1790-1815), desenvolveu-se a cultura da mandioca e do fumo, concentrando-se ai a maior parte da

(40) . - A. N. cx. 507, pacote 2, pacotilha 20, págs. 37-9, op cit.

(41). - Caio Prado Júisor, $c_{\boldsymbol{p}}$. cit., págs. 105-6. 
escravatura, como sendo a primeira tentativa para o progresso de Santa Cruz. Porem, a mandioca foi plantada em excesso; para seu cultivo se fazia a derrubada de matas virgens, abatendo-se por vezes as suas mais ricas madeiras. Dois grandes engenhos foram construidos para o fabrico de farinha, a fim de fornece-la à tropa militar do Rio de Janeiro, aliviando assim a Fazenda Pública de uma consideravel despesa anual só neste gênero; o resultado, porem, não correspondeu ao emprego de tanta mão-de-obra na cultura de dois produtos que eram consumidos, sobretudo, pela população mais pobre, sem conceder altos lucros. A cultura do fumo foi relegada, mas a da mandioca continuou (42). A mandioca era a base da alimentação vegetal da colônia, sendo praticamente cultivada em toda parte.

O arroz e o anil, por sua vez, chegaram a ter relativa importância na economia brasileira no final do século XVIII; o arroz chegou a ocupar o $2^{\circ}$ lugar de nossas exportações, embora em nivel bem inferior ao do açucar, que ocupava o 19 lugar. Embora cultivado no Rio de Janeiro e no Pará, a maior zona produtora de arroz era o Maranhão.

O anil foi introduzido em nosso país mais ou menos em 1769 , sendo que se desenvolvem mais no Rio de Janeiro, cuja exportação alcançou em 1796 o total de 5.000 arroubas; dai em diante, sua produção caiu pela concorrência da Índia (43).

Procurou-se desenvolver tambem, no período por nós focalizado, a cultura do linho cânhamo em Santa Cruz, cuja semeadura, mesmo quando feita fora da época, alcançava bons resultados (44). Alem deste, que já se cultivava no Brasil, havia tambem o chamado linho-de-terra, que depois de preparado era muito mais fino e macio que o europeu (45). As tentativas de desenvolvimento do cultivo do linho cânhamo em Santa Cruz poderiam estar ligadas à política de reconstrução da marinha portuguesa, desenvolvida em fins do século XVIII, uma vez que ele era empregado no fabrico das velas das embarcações marítimas.

Em 1792, tem-se notícia da primeira plantação de café em território da fazenda; uma grande seca, porém, reduzira-a a apenas 4.000

(42). - Op. cit., pág. 308 - "Memórias de Santa Cruz".

(43). - Caio Prado Júnior, op. cit., pág. 86.

(44) . - A. N. cx. 507, pacote 1, pacotilha 12, pág. 1 - Carta de Manoel Martins do Couto Reis, dirigida ao Vice-Rei dando notícias do plantio de semertes de linho cânhamo - 12-2-1799. - A. N. cx. 507, pacote 1, pacotilha 3, documento 4 - págs. 12-4. Relatório do Inspetor da Fazenda de Santa Cruz - 18-6-1790.

(45). - J. J. da Cunha Azeredo Coutinho, op. cit., pág. 82. 
pés; assim mesmo esperava-se plantar, neste mesmo ano, até 40.000 pés (46). Em 1799, começaram a frutificar 20.000 desses pés; o seu cultivo no Brasil, em larga escala, se deu em finais do século XVIII, mas só um pouco mais tarde é que se tornou o grande produto de nossa economia. Antes dessa época, já era cultivado praticamente em toda a colônia, sem valor comercial, porem; servia apenas ao consumo interno nas grandes propriedades.

O cultivo da cana-de-açucar foi tambem incrementado, tendo sido construidos, inclusive, dois engenhos visando a produção do açucar; com isso, desenvolveu-se tambem o fabrico de aguardente.

Devemos ressaltar aqui que, o declínio da mineração na segunda metade do século XVIII favoreceu o ressurgimento das atividades agrícolas. Os conflitos europeus que então se desenvolveram tiveram como uma causa fundamental o problema colonial; assim sendo, atingiram quase sempre as grandes rotas marítimas, contribuindo para a valorização dos produtos coloniais, pois dificultavam e escasseavam o seu fornecimento. Portugal, à sombra da Inglaterra, e já potência de terceira ordem, foi dos paises que menos se envolveram nos conflitos, o que indiretamente beneficiou o Brasil, facilitando o seu comércio. A maioria dos demais produtores de gêneros tropicais viram-se atingindos pelas lutas em que se envolveram suas metrópoles.

Nos últimos anos do século XVIII, os principais concorrentes do Brasil sofreram problemas ainda maiores: as agitações políticas e sociais das colônias inglesas e francesas das Antilhas, principalmente a independência do Haiti em 1792, grande produtor de açucar, cuja produção se desarticulou totalmente com o desenrolar das lutas que envolveram seu movimento emancipador.

A produção açucareira das Antilhas fazia concorrência à produção brasileira; com todos esses conflitos lá, o Brasil se viu numa excelente situação no comércio dos produtos tropicais, inclusive do açucar.

Talvez estes fatos, tendo levado ao incremento da nossa agricultura, possem tambem a causa de se ter, pela mesma época, procurado incentivar o cultivo da cana-de-açucar, bem como a produção do açucar em Santa Cruz: dai, o aumento da lavoura de cana e a construção dos engenhos para o fabrico daquele produto em Itaguai e Piaui, a partir de 1791.

(46) . - A. N. cx. 507, pacote 1, pacotilha 5, págs. 2-3. Carta do Conde de Resende - 27-5-1792. 


\section{C). - A Construção de Fábricas.}

O ponto alto deste período de realizações foi, porem, a construção de dois engenhos de açucar dentro da fazenda, o que muito a valorizou. Santa Cruz tinha tudo quanto era necessário para erguer tais obras sem grandes despesas: mil e tantos escravos entre os quais havia os oficiais necessários para tal serviço, um forno de cal e dois de tijolos, madeiras, pedras e olarias. Nomeado Inspetor da Fazenda de Santa Cruz, o Coronel Manoel Martins do Couto Reis iniciou em 1791 a sua construção. Um deles, de maiores proporções, construido em primeiro lugar, localizava-se em Itaguaí; feito com ótimas madeiras, de pedra e cal, possuia dois ternos de moendas, movidas a água . Foi considerado a mais bela e rica peça do Brasil no gênero, dada a beleza da obra e grandeza do edifício. Em 1794, já se achava em franca produção (47).

Sua localização era excelente: terreno bastante fertil para o cultivo das canas, o seu vantajoso porto para a exportação de seus produtos, a abundância de miatas para a extração da lenha, eram suas qualidades singulares. $O$ fato desse engenho utilizar a água corrente como força motriz de suas moendas é digno de ser destacado, uma vez que isto não era muito comum, na época, aqui no Brasil; das fontes de energia então conhecidas, as mais difundidas no Brasil colônia eram tambem as mais rudimentares: a força do homem e a do animal. A força motriz da água apresentava praticamente o dobro do rendimento da propulsão animal.

O segundo engenho foi erguido no sítio do Piauí, bem na costa do mar, tamben de pedra e cal e com o mesmo cuidado na escolha de materiais; se bem que de menor estrutura e inferior por ser movido à tração animal, tinha igualmente condições de produzir bons lucros. Sua construção foi posterior ao de Itaguaí; iniciado em 1795, mais ou menos, ainda não se encontrava totalmente concluido em 1799 .

Os materiais como pedra, cal e madeira, necessários à construção desses engenhos, foram extraidos do próprio solo da fazenda.

Já em 1790, José Feliciano da Rocha Gameiro admirava-se de que com tão belos terrenos próprios para a produção da cana-de-açucar, que havia, anos já se cultivava na capitania do Rio de Janeiro, Santa Cruz ainda não possuisse três ou quatro engenhos de açucar. Por outro lado, a fertilidade do terreno para a cana era tal que, se-

(47). - A. N. cx. 507, pacote 1, pacotilha 8, pág. 41. Relação da safra de açucar e destilação de aguradente enviada ao Rio de Janeiro, produzida pelo engenho de Itaguaí - 1794 . 
gundo lhe afirmavam, uma plantação que normalmente durava cinco ou seis anos, em Santa Cruz duraria de vinte a trinta anos sem cansar (48).

Outras fábricas tambem existiram ou chegaram a ser cogitadas para a Fazenda de Santa Cruz.

Antes de iniciadas as obras dos engenhos de açucar, já havia na fazenda dos grandes engenhos de mandioca, uma pequena fábrica de anil, um curtume, uma serraria movida a água (que em 1799 estava ainda sem funcionar) e olarias.

No início do século XIX, ha referências à existência de uma fábrica de pólvora (49); nesta mesma época, um tal de Francis Wallis, que parecia ter uma fábrica de lã em Lisboa, solicitou a S. A. R. um empréstimo de 2.000 contos para o estabelecimento de uma fábrica de lã em Santa Cruz. Segundo o plano que ele entregara e fora aprovado, sua fábrica deveria ser construida com conveniência de água, térrea, repartida de modo que os diferentes ramos da manufatura ficassem separados um dos outros; no primeiro compartimento ficaria a lã no seu estado natural e, depois, esta passaria de compartimento em compartimento, em processo regular, até chegar ao armazem onde a fazenda acabada seria depositada para a venda. Tal regularidade impediria confusão e poderia permitir que se descobrisse qualquer perda, caso isto ocorresse. Era uma espécie de produção em massa, ainda que a técnica fosse rudimentar. Real.

$\mathrm{O}$ edifício da fábrica deveria ser construido à custa da Fazenda

Outro empréstimo de 2.000 contos seria necessário para se desenvolver a fábrica e seu pagamento se faria em 2,3 e 4 anos, em parcelas iguais. Esperava Wallis que em 4 anos a fábrica pagaria todas as despesas feitas consigo. Segundo sua proposta, a fábrica seria um estabelecimento nacional de tal qualidade que se tornaria modelo para o resto do Brasil (50). Esta empresa estatal lembra outros similares tanto da Península Ibérica como do Brasil (51).

(48). - A. N. cx. 507, pacote 1 , pacotilha 3 , documento 5 .

(49). - A. N. cx. 507, pacote 2, pacotilha 23, documeżto 2. Balanço das contas da Real Fábrica de Pólvora até o mês de junho de 1811, inclusive $-15-7-1811$.

(50). - A. N. cx. 507, pacote 2, pacotilha 20, págs. 21-2. Carta de Francis Wallis sobre a fábrica de lã de Santa Cruz.

(51). - Nicia Vilela Luz, A política de D. João VI e a primeira tentativa de industrialização no Brasil. Comunicação apresentada no III Simpósio Nacional dos Professores de História, realizado em Franca (São Paulo), em 3-7 de novembro de 1965 . 
A fábrica trabalharia com lãs de Portugal (Elvas e Castelo Branco) e do Brasil (Minas Gerais), servindo aquelas para o urdido e estas para a trama. Segundo o autor do documento, as lãs de Minas demonstravam que lá os pastos eram particulamente próprios para a criação do gado e produção de lã fina; se, durante os primeiros tempos de funcionamento da fábrica, se incentivasse a criação de ovelhas e se prevenisse a matanç̧a de cordeiros, poder-se-ia esperar produção deste tipo de lãs no Brasil suficiente para suprir as fábricas de todo o país (52).

Seria utilizada a mão-de-obra escrava (nas tarefas de pisar a lã, levantar o pelo, tosar, tingir, imprensar) e livre (fiação); entre a mão-de-obra especializada estavam: um mestre tosador, um mestre tintureiro, um mestre cardador de cardas grandes, um mestre cardador de cardas pequenas, um mestre tecelão, um mestre para reger o pisão e um mestre "estambrador" (53).

Em 1815, tambem o holandês Antônio Duffels pretendeu se estabelecer em Santa Cruz com um curtume, a ser construido por sua conta, mas segundo certas condições, a nosso ver bastante exigentes (54). Não pudemos comprovar se sua proposta foi aceita ou não, sendo mais provavel que não tenha sido, devido às exigências feitas.

\section{IV). - O PROBLEMA DE VENDA DA FAZENDA DE SANTA CRUZ.}

Se de um lado, a posição precária de Portugal ante a investida de novos paises industrializados provocava um grande esforço para recuperar sua posição, incentivando a produção nos próprios nacionais, de outro, aquela pressão atingia tal nivel que muitas vezes se cogitou em vender a Fazenda de Santa Cruz a particulares para ter em mãos, de imediato, os recursos financeiros necessários à manutenção dos serviços públicos e à defesa nacional. Assim sendo, mesmo

(52). - A. N. Cx. 507, pacote 2, pacotilha 20, págs. 40-5. Resumo de uma carta de Francis Wallis sobre a fábrica de lã de Santa Cruz.

Tanto este como do documento da referência no 50 estão sem data; mas outros documentos, datados, do mesmo autor sobre o mesmo assunto nos levam a supor que tenham sido redigidos por volta de 1814. (N. da A.).

(53). - A. N. cx. 507, pacote 2, pacotilha 20, pág. 44. Relação da gente precisa para a Real Fábrica de Lanifícios estabelecida na Real Fazenda de Santa Cruz S/D.

(54). - A. N. cx. 507, pacote 2, pacotilha 20, pág. 55 documento 9. Condições em que Antonio Duffels pretende estabelecer um curtume em Santa Cruz. S/D. 
simultâneamente com o esforço de recuperação vinha a idéia de aliená-la.

Já em 1790, José Feliciano Rocha Gameiro recebeu ordem de examina-la, verificando o estado em que se encontrava e os melhoramentos que ela poderia receber para o futuro, quer sob a administração da Fazenda Real ou de particulares, a quem ela fosse vendida ou aforada. Na sua opinião, a fazenda não deveria ser vendida ou aforada a uma só pessoa, devido à sua grande extensão, mas era em geral favoravel à alienação (55) .

Outros, porem, se opunham a tal proposito. Em 1794, o Inspetor Coronel Manoel Martins do Couto Reis queixou-se de que os boatos circulantes na Corte sobre a venda da fazenda atrapalhavam seus planos para a melhoria da mesma, pois caso a venda viesse a ser concretizada, não valeria a pena continuar os esforços despendidos para o seu desenvolvimento (56). Para ele, a fazenda jamais deveria sair do Patrimônio Real. A situação e o lugar em que ela se achava tinham todas as vantagens e comodidades para facilitar contrabandos e extravios e o seu pau-brasil excitaria os ambiciosos. Mantendo a propriedade em mãos reais, estas tendências seriam melhor controladas.

Em suas Memórias de Santa Cruz, o autor faz um Discurso sobre a importância de se retalhar ou vender inteira a Fazenda de Santa Cruz, julgando injuriosa a idéia da venda, afirmando que a Rainha já dera, como de graça, a Fazenda dos Campos, cujos donos, que a possuiam havia mais de dezesseis anos, lucravam, no momento, muito mais de cem mil cruzados anuais. A mesma sorte tinham tido outras fazendas confiscadas aos jesuitas, com as quais a Coroa nada lucrara (57). De modo algum convinha, na sua opinião, a venda da fazenda de Santa Cruz a homens vassalos; o importante seria a sua conservação.

Para obter lucros dela, a Coroa deveria, sim, aforar suas partes incultas, com limites e arrendamentos certos a quem quisesse cultiva-las, concedendo tambem aos foreiros a liberdade para erigirem engenhos ou outras fábricas, prometendo-lhes que não seriam perturbados ou expulsos sem motivo extraordinário. Dessa forma, a Coroa

(55). - A. N. cx. 507, pacote 1, pacotilha 3, págs. 15-8. Vantagens que possa ter a Fazenda de Santa Cruz administrada pela Fazenda Real, pelos particulares ou aforamentos - 22-8-1790.

(56) . - A. N. cx. 507, pacote 1, pacotilha 7, págs. 86-7. Carta de Manoel Martins do Couto Reis, sobre os problemas que lhe trazia a notícia da venda da Fazenda de Santa Cruz - 26-11-1794.

(57) . - Op. cit., pág. 318 - "Memórias de Santa Cruz". 
colheria os dízimos sobre a produção destas terras, do mesmo modo que se as vendesse e elas continuariam no Patrimônio Real; seriam recebidos tambem os foros, que poderiam redobrar com o tempo (naturalmente, cobrando-se mais pela concessão dos aforamentos) . Em alguns anos, teria recebido o valor relativo ao preço da venda, sem te-la vendido.

Assim mesmo, o Vice-Rei D. Fernando José de Portugal, em cumprimento da Carta Régia dirigida a seu antecessor pela Secretaria de Estado dos Negócios da Marinha, de 20-10-1799, convocou uma Junta de Pessoas para tratar da venda da Fazenda de Santa Cruz.

A posição do governo português tinha se tornado ainda mais precária e, às exigências financeiras agora se juntavam considerações ideológicas. $O$ poderio inglês era considerado como fruto do liberalismo e os líderes da época começavam a perguntar-se se não era contra-producente a manutenção de um estabelecimento real como a Fazenda de Santa Cruz.

Na primeira reunião da Junta convocada por D. Fernando José de Portugal, todos foram favoraveis à venda, lembrando, entretanto, que se conservasse os campos de pastos (58). Essa preocupação pela não alienação das pastagens foi constante em todos os pareceres emitidos, quer sobre a venda da fazenda em seu conjunto, quer sobre a venda dos engenhos de ltaguaí e do Piauí (59). Esses pastos eram essenciais ao suprimento de carne para a florescente cidade do Rio de Janeiro e neste particular a mentalidade antiga continuava inabalada.

Os argumentos principais dos que se mostravam favoráveis à negociação da fazenda de Santa Cruz eram: a possibilidade de abatimento da dívida real, com o dinheiro conseguido na transação, e a má administração vigente naquela propriedade, devido à incapacidade do corpo administrativo.

A Coroa se preocupava com a possibilidade de que a venda da fazenda a particulares tornasse mais facil uma invasão estrangeira por esse lado da costa brasileira. Para alguns, a defesa da costa não seria prejudicada, pois um terreno seria tão mais defensavel quanto mais populoso fosse, pois os colonos teriam mais zelo do que os es-

(58). - A. N. cx. 507, pacote 2, pacotilha 15, pág. 6. Carta de D. Rodrigo de Souza Coutinho dirigida a D. Fernando José de Portugal, sobre a venda da Fazenda de Santa Cruz - 11-8-1802.

(59). - Em alguns documentos são utilizados, indistintamente, os têrmos Taguaí e Itaguaí, Piaí e Piauí. (N. da A.). 
cravos em defender a terra em que viviam; para outros, o exército seria a melhor solução para a defesa . mos destacar:

Dentro da corrente pró-venda da fazenda de Santa Cruz pode-

a). - o Desembargador Procurador da Coroa, Francisco de Sousa Guerra Godinho (60), que afirmava que a má administração atingia até os escravos, que não eram bem tratados, faltando-lhes inclusive o vestuário; estes, por sua vez, não eram bem disciplinados, caracterizando-se pela "pouca sujeição" (61);

b) : - o Deputado Tesoureiro Geral, favoravel à venda por lotes, isto é, o território da fazenda seria dividido em vários lotes, que seriam negociados separadamente; duvidava muito, porem, que a Coroa pudesse alcançar com a transação os 2.500 .000 cruzados que ela pretendia; ele tambem comentava a falta de zelo dos administradores em relação aos escravos (62);

c) . - José Feliciano da Rocha Gameiro, tambem favoravel à venda por lotes; lembrava ele que já estava se tornando dificil achar terrenos próximos à cidade em que se empregassem agricultores; o Erário Régio estava sendo, pois, prejudicado nos dízimos e demais direitos de exportação que the dariam esses terrenos, se repartidos (63) .

Este sistema de venda parcelada encontrou apôio em outros vultos da época. Luis Beltrão de Gouveia, em carta dirigida a D. Rodrigo de Souza Coutinho em 14-5-1799, mostrou-se favoravel a tal procedimento, apresentando inclusive um plano de divisão de suas terras com o preço que cada uma de suas partes poderia alcançar na transação; afirmava que não havia ninguem que pudesse comprá-la inteira (64) .

José Caetano de Lima foi da mesma opinião (65).

(60) . - A. N. cx. 507, pacote 2, pacotilha 15, págs. 7-9. Carta do Desembargador Procurador da Coroa a D. João, sobre a venda da Fazenda de Santa Cruz - 10-9-1802.

(61). - Ibidem.

(62). - A. N. cx. 507, pacote 2, pacotilha 15, pág. 18. Parecer do Deputado Tesoureiro Geral sobre a Carta Régia respectiva à venda da Fazenda de Santa Cruz (2-10-1802).

(63). - A. N. cx. 507, pacote 2 , pacotilha 15 , págs. 5 e 19.

(64). - Revista do IHGB - Tomo 65 - págs. 281-5.

(65) - - A. N. cx. 507, pacote 2 , pacotilha 15, págs. 3-4. Considerações relativas à Fazenda de Santa Cruz - 15-5-1802. 
Ainda em 1805, continuavam sendo levantadas questões referentes a este assunto, como se pode depreender do documento assinado pelo Conselheiro Chanceler José Pedro Machado Coelho Torres, de 14-9-1805 (66) .

Apesar de contar com um grande número de opiniões favoraveis, a idéia da possibilidade da venda de Santa Cruz tambem tem opositores, sendo, talvez, o mais acirrado deles o já mencionado Inspetor Coronel Manoel Martins do Couto Reis.

O certo é que, embora a fazenda não tenha sido vendida totalmente, duas de suas mais importante porções o foram: os engenhos de Itaguaí e de Piauí, pouco tempo após sua construção. Pela Carta Régia de 7-11-1803, o Príncipe Regente ordenou que se vendesse os dois engenhos de açucar, com os terrenos necessários para suas atividades, com o cuidado, porem, de não se incluir na sua demarcação os campos destinados à pastagem do gado e os terrenos do cultivo da mandioca. Ao Juiz dos Feitos da Coroa e Fazenda, Desembargador Manoel Carlos da Silva Gusmão, ordenou S. A. R. que demarcasse e avaliasse os referidos engenhos.

O Coronel Manoel Martins do Couto Reis protestou energicamente contra tal medida. Dizia ele que, iniciado em 18-6-1804 e concluindo em 20-12-1804, o Tombo fora realizado com uma série de irregularidades propositais, entre as quais a inclusão, como terrenos do engenho do Piauí, para a venda, de uma parte do campo, de certas zonas mais altas reservadas para refúgio do gado na época das inundações e das terras reservadas à cultura da mandioca e às roças dos escravos, todos os quais, segundo a Real Determinação, deveriam ser preservados como propriedade real. O primeiro piloto, Simão Antônio da Rosa Pinheiro, ao reclamar dos erros que o forçavam a cometer, teria sido ameaçado e "vituperado", no dizer do Coronel Manoel Martins do C. Reis. Outrossim, as avaliações das terras da fazenda, haviam sido feitas, na sua opinião, de acordo com o valor atribuido às terras vizinhas, estéreis e longe dos portos de embarque, muito inferiores em valor às de Santa Cruz, fertilíssimas e com admiráveis portos (67).

(66) . - A. N. cx. 507, pacote 2, pacotilha 18, págs. 18-9. Documento assinado pelo Conselheiro Chanceler José Pedro Machado Coelho Torres, sobre a venda da Fazenda de Santa Cruz - 14-9-1805.

(67) . - Revista do IHGB - Tomo V - 1843 - págs. 178-183. "Mediçōes e demarcações de limites nos dois prédios de Taguaí e Piaí, que em consequência daordem real se devem vender desanexando-os da Fazenda de Santa Cruz - 1804 . 
No caso de ser verdadeira a denúncia quanto à avaliação dos terrenos, tal manobra poderia representar, em nossa opinião, uma tentativa de fazer baixar o preço da venda da fazenda, permitindo aos seus autores ou a quem eles representavam, adquiri-la mais facilmente.

Em carta dirigida a D. Fernando José de Portugal, datada de 7-11-1803, Luis de Nascimento e Souza teve a mesma preocupação relativa à demarcação dos engenhos: recomendava que se declarasse que não deviam ser incluidos nos terrenos destinados aos engenhos os campos em que os compradores de gado arrendavam pastagens, com prejuizo da Fazenda Pública, bem como deviam tambem ser reservados os terrenos e matas necessárias para a mandioca da tropa e da escravatura que ficassem para as plantações (68).

As mesmas irregularidades ocorridas no Tombo do engenho do Piauí teriam ocorrido no do engenho Itaguaí; o Coronel Manoel Martins do C. Reis escreveu a D. Fernando José de Portugal, em 23-10-1804 , denunciando o escandaloso prejuizo que se estava por inflingir aos interesses do Príncipe e que deveria ser evitado.

Tudo o que se estava fazendo nas demarcações riaquele momento ia contra as ordens de D. Fernando ou contra as Reais recomendações: desanexação de terras da fazenda para as incluirem nas dos engenhos, justamente aquelas que reiteradamente se havia recomendado que permanecessem fora dos limites dos engenhos (69). Para o Coronel, o dinheiro arrecadado com a venda dos engenhos jamais compensaria os prejuizos futuros da Fazenda Real.

Os documentos que consultamos não revelam os nomes daqueles que adquiriram os engenhos.

Os motivos que teriam levado à proposição da venda da Fazenda de Santa Cruz podem ser parcialmente explicados pela própria incapacidade da Coroa portuguesa em explorar tão extensa propriedade; isto só seria viavel mediante o investimento de vultosos capitais que semelhante empresa envolvia e que ela, a Coroa, não possuia.

Por outro lado, dada a riqueza de semelhante patrimônio como era Santa Cruz, é bem provavel que houvesse interesse por parte de

(68). - A. N. cx. 507, pacote 2, pacotilha 18 - pág. 4. Carta de Luiz de Nascimento e Souza dirigida ao Vice-Rei D. Fernando José de Portugal sobre algumas dúvidas na demarcação dos engenhos da Fazenda de Santa Cruz, para a sua venda, na forma determinada na Carta Régia de 7-11-1803.

(69). - "Carta de Manoel Martins do Couto Reis dirigida a D. Fernando José de Portugal sobre o problema da demarcação dos engenhos a serem vendidos" 23-10-1804. Revista do IHGB. Tomo V, págs. 181-3. 
determinađos grupos, financeiramente bem dotados, por aquela transação, interessados que estavam em possui-la. Esta hipótese é bem mais provavel no que se refer» à venda dos engenhos, que realmente chegou a ser concretizada.

Não sabemos ainda, no presente, estágio deste nosso estudo, se a produção dos enegenhos de açucar de Santa Cruz fazia concorrência a outros, particulares, dai a pressão para que a Coroa se desfizesse deles, ou se os engenhos eram desejados para serem utilizados e produtivos ou se os motivos pelos quais tantos indivíduos importantes defendiam sua venda eram outros, como o problema da dívida da Coroa, apontada como causa fundamental, ou ainda outros, menos confessaveis.

O certo é que, estando a Coroa portuguesa em péssima situação financeira, à beira da falência, a venda da fazenda ou de partes importantes da mesma realmente poderia ser encarada como a única solução possivel pra o resgate da dívida pública.

A venda da fazenda, totalmente, de uma só vez, não foi realizado pois não havia, no momento, quem tivesse o capital necessário para arremata-la.

Os engenhos, porem, foram realmente vendidos e as recomendaçõe reais não foram levadas em conta, pelo menos parcialmente: em um documento datado de 1814 há referências à falta de terras para as plantações dos escravos depois da venda dos dois engenhos (70).

\section{V). - ASPECTOS ADMINISTRATIVOS.}

Toda uma ampla burocracia se encarregava do andamento dos negócios de Santa Cruz. Os documentos nos informam acerca dos seus principais funcionários.

O mais graduado dentre estes era o Superintendente; alem dele havia: o inspetor geral, o administrador, dois ajudantes, tres escreventes, um fiel para o armazem do depósito, oito feitores maiores; oito feitores menores e um campeiro-mor.

Os feitores menores poderiam ser um menor número ou não existirem caso houvesse escravos de boa conduta a quem se encarregasse

(70). - A. N. cx. 507, pacote 2, pacotilha 24, documento 3, pág. 27. Carta do $1^{\text {o }}$ Administrador João Fernandes da Silva ao Ilmo. Sr. Conselheiro Superintendente sobre a justiça da concessão de pensão à viưva de um campeiro - 3-3-1814. 
de certas incumbências; todos esses elementos não seriam admitidos de uma só vez mas, sim, à proporção que se fizessem necessários (71).

Nas Instruções Provisionais para a administração da Fazenda de Santa Cruz, de 20-9-1808, ficaram fixadas as funções do superintendente; dos $1^{\circ}$ e $2^{\circ}$ administradores; do Almoxarife dos Paços e Diretor das manadas de cavalos, éguas e bois de serviço; dos $1^{\mathbf{0}}$ e $2^{\circ}$ escriturários.

O documento não se refere ao cargo de inspetor que, pelo que se pode deduzir de outras fontes anteriores a esta data, estaria situado na escala hierárquica imediatamente acima do de administrador; este, que antes era apenas um, pois os documentos não faziam referência ao $1^{\circ}$ ou $2^{\circ}$ administrador, mas ao administrador, simplesmente, agora parece ser em número de dois (72).

Entre as funções do superintendente, de acordo com as Instruções Provisionais estavam as seguintes:

a). - a ele seriam subordinadas todas as pessoas empregadas em Santa Cruz, na administração e trabalhos de qualquer ordem ou condição;

b). - ele regularia os trabalhos de agricultura e indústria, de acordo com os administradores e empregados, cada um privativamente no ramo de que estivesse incumbido; em caso de duvida, prevaleceria sua opinião, suas deliberações seriam comunicadas a S. A. R. atraves do Presidente do Real Erário, bem como a instalação de todos os novos estabelecimentos que julgasse necessário;

c) - - poderia mandar vender, quando e como julgasse mais conveniente, os gêneros de agricultura e de indústria, madeiras, gados vacum e equino, recolhendo o seu produto ao cofre da administração;

d). - mandaria pagar, por despacho, à boca do cofre, todas as despesas de ordenados e do custeio da fazenda, com as legalidades da Real Coroa;

e). - estabeleceria, ouvindo o $1^{\circ}$ administrador, o melhor método que the parecesse conveniente ao tratamento, disciplina e polícia dos escravos, a fim de conseguir a sua conservação e aumento, pro-

(71). - A. N. cx. 507, pacote 2, pacotilha 20, págs. 7-8. Novas reflexões sobre um melhor plano para a administração da Real Fazenda de Santa Cruz.

O documento está sem data e sem assinatura. (N. da A.).

(72). - A. N. cx. 507, pacote 2 , pacotilha 21, págs. 2-7. Instruções provisionais para a administração da Fazenda de Santa Cruz - 20-9-1808. 
movendo os casamentos, e a fim de que se pudesse tirar do seu trabalho o melhor rendimento possivel;

f) . - daria conta, anualmente, a S. A. R. pelo Presidente do Real Erário, do Estado do Cofre da Administração, acompanhando o Balanço de Receita e Despesa uma memória ou exposição de todos os melhoramentos que no decurso do ano se tivesse obtido tanto nos obtido tanto nos objetos de cultura já estabelecida e nas que de novo se introduzissem, como nos objetos de indústria, com tabelas em que se visse claramente qual fora a produção de toda a espécie naquele ano e qual o rendimento líquido, comparado com o do ano antecedente;

g). - poderia procurar todo o dinheiro que necessitasse para as despesas correntes a $5 \%$ ao mês, quando faltassem fundos no Cofre da Administração, pagando-se sucessivamente o juro e o capital, logo que fossem entrando os rendimentos da fazenda, dando no fim do ano uma conta particular do que a esse respeito tivesse feito, juntamente com os balanços.

Ao 19 administrador caberia, entre outros encargos:

a) . - a administração da fazenda de Santa Cruz, sob a inspeção do superintendente, a quem deveria sempre propor tudo quanto julgasse conveniente aos interesses da mesma, não somente a respeito das atuais culturas, mas das novas que se empreendessem pelos métodos e práticas da bem entendida agricultura, que tanto florescia na Inglaterra, seja pela introdução dos instrumentos mais apropriados, seja pela alteração das culturas e conveniente adubo e preparação da terra;

b). - seria igualmente encarregado de todos os objetos de indústria que fosse possivel e conveniente estabelecer, tendo particular cuidado sobre a manufatura de manteiga e queijo;

c) . - deveria dar particular atendendo ao aumento do gado vacum e ao melhoramento de sua raça para que houvesse maior número de vacas mansas e de boa qualidade, para se poder fazer manteiga e queijo com abundância, estabelecendo a divisão de pastos. Quando da transferência da Corte portuguesa para o Brasil, a administração da Fazenda de Santa Cruz recebeu especial atenção.

Em fins de agosto de 1808 foram nomeados:

- Leonardo Pinheiro de Vasconcelos, integrante do Conselho de Estado, como Superintendente.

- João Mawe, como primeiro administrador. 

nistrador.

- João Fernandes da Silva como tesoureiro e segundo admi-

- Francisco Damazo, como almoxarife dos Paços e Diretor das manadas de cavalos, éguas e bois do serviço da fazenda de Santa Cruz (73).

\section{VI). - CONCLUSÃO.}

Apesar de se pretender fazer de Santa Cruz uma unidade econômica mais rentavel, de se buscar meios que promovessem o seu desenvolvimento, vários fatores prejudicaram as iniciativas feitas nesse sentido, impedindo a total realização do objetivo visado.

Um desses fatores foi o próprio tamanho da fazenda: estendendo-se desde o litoral, na pedra de Guaratiba, até a Serra de Mata-Cães, em Vassouras, ela constituia um imenso latifúndio cuja exploração demandava grande quantidade de recursos, não só humanos mas sobretudo financeiros, que a Coroa portuguesa não estava em condições de dispensar no momento.

A natureza, por sua vez, tambem contribuia bastante para impedir um progresso mais efetivo de Santa Cruz: durante todo o verão as fortes chuvas que caiam sobre o Rio de Janeiro inundavam grande parte da fazenda, formada por inúmeras zonas de planície, ao provocarem o transbordamento dos rios Guandú e Itaguaí, destruindo plantações, matando o gado, estragando os pastos, dificultando e até mesmo impedindo a locomoção dentro da fazenda .

O sistema de comunicações, por sua vez, era outro fator de destaque, entravando o desenvolvimento daquela propriedade; a falta de estradas no interior da fazenda dificultava o transporte das produções, da mão-de-obra e dos próprios funcionários encarregados da administração e fiscalização dos seus negócios; fazia tambem com que existisse ainda muita terra devoluta e inculta. Os poucos caminhos existentes eram muito mal conservados, não havendo geralmente nem valas para o escoamento das águas que sobre eles caiam quando chovia. Houve algumas tentativas de se remediar a situação, mas muito incipientes, não chegando a alterar o quadro geral. Em 1790, há referências à abertura de um "caminho novo", por ordem da Pro-

(73). - Todos foram nomeados de acordo com o Decreto Real de 31-8-1808. 
visão de 20-6-1789; em 1794, os documentos citam a construção de pontes no interior da fazenda (74).

Em 1795, as tropas que vinham de Minas e São Paulo teriam externado sua gratidão pelas melhorias feitas nos caminhos que percorriam pela Fazenda, em demanda do Rio de Janeiro. Lembrou Samuel Bennet a necessidade de se cuidar das estradas da fazenda, sugerindo a construção de uma boa estrada pública; segundo ele, naquele momento (1812) a fazenda estava quase intransitavel (73), provavelmente pela ocorrência de fortes chuvas.

A Coroa portuguesa, por sua vez, não dispunha dos recursos financeiros a serem empregados em grande escala para fazer de Santa Cruz uma unidade produtiva altamente rentavel. Todo o capitalista sabe que para ganhar dinheiro é necessário gasta-lo tambem.

Ora, a Coroa neste momento estava exatamente em condições contrárias. A possibilidade de transformar a fazenda numa propriedade rentavel dependeria, primeiro, de tempo e, segundo, de capital.

Estes eram precisamente o que faltava ao antigo poder colonial, pois a crise era atual e marcante.

Entretanto, pelo exame feito dos documentos, parece-nos que um dos fatores que mais influiram impedindo o progresso de Santa Cruz, foi a incapacidade administrativa de seus funcionários, ou, melhor explicando, a falta de interesse dos elementos encarregados de zelar pelos seus negócios. Manoel Martins do C. Reis lamentava, em 1793, a falta de método que vinha transtornando o rico tesouro que era Santa Cruz (76).

Leonardo Pinheiro de Vasconcelos, encarregado por S. A. R. de uma comissão na fazenda de Santa Cruz, queixou-se da oposição que lhe fizeram os funcionários mais graduados, a quem ele tinha advertido de suas faltas e deveres e a quem via na rigorosa necessidade de suspender; o escrivão e os administradores não aprontavam a escrituração que ele lhes solicitava; uns, por tirarem proveito disso e outros por desleixo e inaptidão (77).

(74) . - A. N. cx. 507, pacote 1, pacotilha 7, documento 6, pág. 28, Carta de Manoel Rodrigues Silvano sobre a construção de pontes na Fazenda de Santa Cruz - 25-2-1794.

(75). - A. N. cx. 507, pacote 2, pacotilha 20, págs. 37-9. Carta de Samuel Bennet ao Conde de Linhares dando notícias das providências a serem adotadas em Santa Cruz (sem data).

(76) . - A. N. cx. 507, pacote 1, pacotilha 6, pág. 5. Carta de Manoel Martins do Couto Reis, sobre a Fazenda de Santa Cruz - 3-8-1793.

(77) . - A. N. cx. 507, pacote 2, pacotilha 20, págs. 40-1. Carta de Leonardo Pinheiro de Vasconcelos dirigida a Antônio de Araujo de Azevedo 24-1-1815. 
Em 1799, Luiz Beltrão de Gouveia de Almeida escrevia a D. Rodrigo de Souza Coutinho acerca de Santa Cruz dizendo não entender o paradoxo que era a administração de Santa Cruz; referia-se às contínuas mudanças de administradores que ocorriam havia muito tempo: militares, civis, ministros, todos tinham exercitado seus talentos sem fruto ou utilidade, quer dizer, sem realizarem, na prática, nada de realmente positivo pelo desenvolvimento de Santa Cruz. Afirmava que os escravos morriam de fome e andavam nus, tendo para comer e vestir apenas o trabalho dos sábados; escravos, bestas, gado, terras, pastos, tudo era desfrutado e eram tantos os que desfrutavam quantos governavam no Rio de Janeiro, fosse político ou militar, criados e os protegidos, todos tinham o direito de desfrutar da fazenda (78). Nos parece que havia, no momento, desentendimentos entre o Luiz Beltrão, que defendia seu parecer favoravel à venda de Santa Cruz, e o administrador desta, Maneel Martins do Couto Reis, opositor ferrenho de tal medida, segundo fonte consultada (79). Mesmo levando-se em conta o possivel exagero de suas afirmativas, pois Luiz Beltrão provavelmente estava defendendo seus interesses pessoais, pode-se entrever ai que, de fato, a administração não corria tão bem como deveria; aliás, não era do interesse da burocracia administrativa de Santa Cruz defender o progresso dela, mas, sim, procurar tirar para si os melhores proveitos possíveis, enquanto ocupassem aqueles cargos. As próprias dissenções que ocorriam entre os funcionários já era um fator extremamente prejudicial ao desenvolvimento normal das atividades da fazenda.

Em 1815, Francisco Cordeiro da Silva Torres referia-se ao número excessivo dos empregados que viviam com os ordenados e raçōes avultadas e às obras em acomodações e outros muitos trabalhos não produtivos, necessários à comodidade das jornadas de S. A. R. que absorviam grande quantidade de recursos do Erário Régio (80). Isto demonstra que mesmo com a transferência da Corte portuguesa para o Brasil, ou ainda mais com esta transferência, o sistema colonial não se alterava, entravando com gastos improdutivos o progresso do país.

Em resumo, apesar de todos os esforços dispendidos para um mais pleno desenvolvimento de Santa Cruz, a par de todas as causas

(78). - Revista do IHGB, Tomo 65, parte I, págs. 281-5. "Carta de Luiz Beltrão Gouvea de Almeida sobre a venda da Fazenda de Santa Cruz" 14-5-1799.

(79). - Revista do IHGB - Tomo V - 1843 - págs. 178-183; op. cit.

(80) - - A. N. cx. 507, pacote 2, pacotilha 25, documento 14 , págs. 52-65. Observações sobre a'administração da Fazenda de Santa Cruz. Francisco Cordeiro da Silva Torres - 15-12-1815. 
acima apontadas, o objetivo visado não pôde ser alcançado porque o Estado, representado pela Coroa portuguesa, não tinha condições de arcar com tão avultado empreendimento pois não possuia capital para isso.

Empobrecido, o reino portguês só sobreviveu ainda nesta época como potência colonial à sombra do poderio inglês. O fracasso da política de fomento econômico de toda a colônia revela-se uma vez mais em Santa Cruz. Nesse paradoxo entre uma metrópole pobre e uma colônia riquíssima acionou todo um mecanismo de tensões que acabaram por conduzir à separação entre o Brasil e Portugal. 